\title{
ANALISIS TINGKAT KEBUTUHAN DAN KEMAMPUAN PENYEDIAAN KONSUMSI KEDELAI DI KABUPATEN GARUT
}

\section{ANALYSIS OF NECESSITY LEVEL AND STOCK ABILITY OF COMSUPTION SOYBEAN IN GARUT REGENCY}

\author{
M. N. Adinasa ${ }^{1}$ \\ ${ }^{1}$ Fakultas Pertanian Universitas Garut, Jl. Raya Samarang No. 52 Garut, 44151, \\ Indonesia, E-mail:nu'manadinasa@uniga.ac.id
}

\begin{abstract}
ABSTRAK
Tujuan penelitian ini untuk mengetahui: 1) kemampuan penyediaan kedelai pada tahun 2012 di Kabupaten Garut dan 2) prediksi kebutuhan konsumsi kedelai di Kabupaten Garut 5 tahun ke depan. Studi ini telah diselenggarakan dari Mei sampai Juli 2013. Pengumpulan data dalam wujud data deret waktu (time series) di dalam 10 tahun terakhir (2003-2012), data sekunder tersebut meliputi banyaknya penduduk, luas panen yang diukur dalam ha (hektar), produksi dan produktivitas kedelai pada setiap tahunnya di Kabupaten Garut, data tersebut selanjutnya diolah untuk menentukan hasil yang dibutuhkan untuk peramalan pemenuhan data kebutuhan dan kemampuan untuk menyediakan konsumsi kedelai di Kabupaten Garut. Data dianalisis menggunakan analisis deskriptif dan kualitatif sederhana untuk menentukan pemenuhan kebutuhan dan kemampuan konsumsi terhadap komoditas kedelai, untuk mendapatkan peramalan kebutuhan kedelai di Kabupaten Garut 5 tahun kedepan dilakukan dengan menggunakan data terakhir dari instansi terkait, analisis kecenderungan (trend analysis), dan analisis deret waktu. Hasil analisis menunjukkan kemampuan Kabupaten Garut dalam pemenuhan kedelai yang akan siap untuk dikonsumsi sebesar 21.462 ton pada tahun 2012, hasil ini belum melampaui kebutuhan yang harus disediakan Kabupaten Garut pada tahun tersebut yang berjumlah 25.178,44 ton kedelai. Pada tahun 2017 produksi kedelai Kabupaten Garut diramalkan akan menghasilkan sejumlah 23.655 ton sedangkan kebutuhan kedelainya diramalkan sebesar 26.807,96 ton, dengan jumlah sebesar itu, Kabupaten Garut masih belum mampu memenuhi kebutuhan perkapita penduduknya untuk komoditi kedelai.
\end{abstract}

Kata Kunci: kedelai, proyeksi, kebutuhan, penyediaan 


\begin{abstract}
The purpose of this research to find out: 1) Capability of providing soybean in 2012 in Garut regency and 2) Prediction of soybean consumption in Garut regency next 5 years. This study was held from May until July 2013. Data collected in the form of time series data within 10 years (2003-2012) including secondary data about a lot of people, a large harvest (measured in hectare), soybean production and productivity in Garut regency each year, these data are processed to produce a forecast of the demand and supply of soybean consumption in Garut regency. Data were analyzed using descriptive analysis and simple calculations to determine the fulfillment of needs and abilities of the provision of soybean, while for predicting soybean needs in Garut regency for the next 5 year by using least squares from related agencies, trend analysis and time series analysis. The resulting analysis shows that the ability of Garut regency in the fulfillment of soybean will be ready to be consumed by 21.462 tons in 2012 this result isn't beyond needs to be provided by Garut regency in that year, which needs 25.178,44 ton soybean. In 2017 soybean production of Garut predicted would be producing 23.655 tons and the needs of soybean foreseen about 26.807,96 tons. With that amount, Garut regency still unable to meet the needs of its citizens per capita for soybean commodity.
\end{abstract}

Keywords: Soybeans, forecast, Supply, Demand

\title{
PENDAHULUAN
}

Tanaman pangan merupakan kebutuhan pokok manusia yang tidak bisa diabaikan, karena bagaimanapun manusia tidak bisa lepas dan akan selalu mengonsumsi pangan. Oleh sebab itu, pangan menjadi komoditas penting dan strategis yang ketersediaannya di tengah masyarakat tidak boleh kurang untuk menjamin kehidupan mereka dan stabilitas politik dalam sebuah negara. Hal tersebut tertuang dalam UU No. 18 Tahun 2012 tentang pangan. Isi dari UU tersebut menyatakan tentang posisi pangan sebagai kebutuhan dasar manusia yang paling utama pemenuhannya, kemudian kewajiban negara dalam pemenuhan ketersediaan pangan di tengah masyarakat.

Kebutuhan akan bahan pangan terus meningkat seiring peningkatan jumlah penduduk yang ada di Indonesia. Tiga komoditi pokok yaitu beras, jagung dan kedelai nilainya masih belum mencukupi kebutuhan penduduk Indonesia yang berjumlah 259.940.857 jiwa, hal ini dibuktikan dengan adanya impor bahan pangan sepanjang tahun 2012 yakni impor beras yang mencapai angka 1,95 juta ton, jagung 2 juta ton, kedelai 1,9 juta ton (Utomo, 2012). Oleh karena itu peningkatan produksi dan produktivitasnya harus terus diupayakan semaksimal mungkin. Jawa Barat dengan populasi penduduk terbesar seIndonesia memiliki kebutuhan pangan dalam jumlah besar pula, data BPS Jawa Barat (2012) menunjukkan angka 43.826.775 jiwa pada akhir tahun 2011.

Gubernur Jawa Barat menyatakan, untuk memenuhi kebutuhan pangan baik secara kualitas, kuantitas, keamanan, pemerataan dan keterjangkauan, 
khususnya dalam rangka mempertahankan pencapaian Angka Kecukupan Energi (AKE) minimal sebesar 2.200 Kilo Kalori/Kapita/Hari, serta meningkatkan Pola Pangan Harapan (PPH) agar mencapai PPH ideal yaitu sebesar 100 poin, maka perlu diperhatikan aspek keberagaman pola konsumsi. Pengaturan pola dengan kombinasi dasar pangan diharapkan mampu menekan tingkat konsumsi bahan pangan padi-padian, terutama beras. Hal tersebut menegaskan akan lemahnya konsumsi masyarakat Jawa Barat dalam mengonsumsi pangan selain beras, dengan mengupayakan peningkatan pola konsumsi selain beras ini produksi pangan di Jawa Barat harus terus ditingkatkan demi pencapaian tujuan seperti dimaksudkan di atas (Bowo, 2011).

Kedelai merupakan komoditas pangan terpenting ketiga setelah padi dan jagung. Selain itu, kedelai juga merupakan tanaman palawija yang kaya akan protein, sehingga mempunyai peran yang sangat penting dalam industri pangan dan pakan. Kedelai merupakan salah satu sumber protein nabati yang paling banyak dikonsumsi masyarakat, karena harganya yang relatif terjangkau. Produksi kedelai sebelum tahun 2003 cenderung menurun, namun sejak tahun 2004 terlihat adanya peningkatan kembali. Penurunan produksi ini, terutama sejak tahun 1992 antara lain disebabkan masuknya kedelai impor dengan harga murah dalam jumlah besar. Kondisi ini menyebabkan petani sulit bersaing dengan kedelai impor (Badan Penelitian dan Pengembangan Pertanian, 2005).

Kabupaten Garut sampai akhir tahun 2011 tercatat produksi kedelai yang dihasilkan merupakan jumlah terbesar dibandingkan daerah lain di Jawa Barat, sebagaimana dapat dilihat pada Tabel 1.

Tabel 1. Data Luas Panen, Produksi dan Produktivitas Kedelai Jawa Barat Tahun 2015

\begin{tabular}{|c|c|c|}
\hline No. & Kota/Kabupaten & Produksi (Ton) \\
\hline 1. & Bogor & 0 \\
\hline 2. & Sukabumi & 9.365 \\
\hline 3. & Cianjur & 7.905 \\
\hline 4. & Bandung & 760 \\
\hline 5. & Garut & 21.433 \\
\hline 6. & Tasikmalaya & 6.467 \\
\hline 7. & Ciamis & 2.978 \\
\hline 8. & Kuningan & 1.061 \\
\hline 9. & Cirebon & 389 \\
\hline 10. & Majalengka & 5.007 \\
\hline 11. & Sumedang & 1.732 \\
\hline 12. & Indramayu & 29.101 \\
\hline 13. & Subang & 379 \\
\hline 14. & Purwakarta & 211 \\
\hline 15. & Karawang & 2.442 \\
\hline 16. & Bekasi & 1 \\
\hline 17. & Bandung Barat & 3.010 \\
\hline 18. & Pangandaran & 3.868 \\
\hline
\end{tabular}




\begin{tabular}{rlr}
\hline No. & Kota/Kabupaten & \multicolumn{2}{c}{ Produksi (Ton) } \\
\hline Kota & & \\
19. & Tasikmalaya & 341 \\
20. & Banjar & 487 \\
\hline Total & & $\mathbf{9 6 . 9 3 7}$ \\
\hline Rata-rata & & $4.846,85$ \\
\hline
\end{tabular}

Sumber : BPS Provinsi Jawa Barat, 2012

Tabel 1 menunjukkan, bahwa Kabupaten Garut merupakan produsen kedelai tertinggi dibanding 19 daerah lain, dengan Cianjur dan Ciamis sebagai penghasil kedua dan ketiga, sedangkan 6 kota di Jawa Barat yaitu Bogor, Bandung, Cirebon, Bekasi, Depok dan Cimahi tercatat tidak memproduksi kedelai di tahun tersebut. Ini didukung dengan keadaan alam yang dimiliki oleh Kabupaten Garut. Namun produksi di Garut pun tiap tahun mengalami fluktuasi, dari data yang tercatat tahun 2003-2012, pada tahun 2007 produksi kedelai di Garut mencapai angka terendah yakni 6.397 ton dan pada 2012 mencapai angka tertinggi dengan jumlah produksi 21.462 ton seperti dapat dilihat pada Tabel 2 .

Tabel 2. Data Kedelai Kabupaten Garut Tahun 2003-2012

\begin{tabular}{llrrr}
\hline No. & Tahun & Luas Panen (Ha) & Produksi (Ton) & Produktiviras (Ton/Ha) \\
\hline 1. & 2004 & 7.361 & 8.936 & 1,214 \\
2. & 2005 & 5.418 & 7.098 & 1,310 \\
3. & 2006 & 5.936 & 7.883 & 1,327 \\
4. & 2007 & 4.554 & 6.397 & 1,405 \\
5. & 2008 & 5.584 & 7.858 & 1,407 \\
6. & 2009 & 8.343 & 12.646 & 1,516 \\
7. & 2010 & 11.453 & 18.603 & 1,624 \\
8. & 2011 & 9.461 & 15.406 & 1,628 \\
9. & 2012 & 13.106 & 21.462 & 1,637 \\
10. & 2013 & 12.945 & 21.441 & 1,656 \\
11. & 2014 & 15.535 & 25.938 & 1,670 \\
12. & 2015 & 13.198 & 21.433 & 1,624 \\
13. & 2016 & 7.917 & 12.857 & 1,624 \\
14. & 2017 & 6.170 & 10.069 & 1,632 \\
15. & 2018 & 10.657 & 17.318 & 1,625 \\
\hline
\end{tabular}

Sumber : Dinas Tanaman Pangan dan Hortikultura Kabupaten Garut, 2013

Kebutuhan penyediaan kedelai untuk agroindustri di Kabupaten Garut pada awal tahun 2013 masih sangat minim, meskipun jumlah produksinya terbesar se-Jawa Barat. KOPTI (Koperasi Tahu Tempe Indonesia) Kabupaten Garut mencatat untuk pembuatan tahu dan tempe saja dibutuhkan sedikitnya 600.000 ton kedelai per-bulan. Pabrik kedelai MDL 525 pun membutuhkan bahan baku kedelai sekitar 60 ton per bulan (www.garutkab.go.id). 


\section{METODOLOGI}

\section{Lokasi dan waktu penelitian}

Penelitian ini merupakan jenis penelitian yang dilakukan secara kuantitatif dengan menggunakan data historis perkembangan produksi kedelai di Kabupaten Garut. Data yang digunakan merupakan data sekunder dengan mencari ke pihak-pihak dan lembaga yang berwenang seperti BPS, Dinas Pertanian, serta pihak lainnya yang memiliki data pendukung dalam penelitian ini, data yang dihimpun sebagai dasar penelitian yang sangat diyakini keabsahannya untuk menghasilkan analisis tentang keadaan yang mampu merepresentasikan keadaan yang ada di lapangan. Penelitian ini dilaksanakan pada instansi-instansi di Kabupaten Garut yang memiliki informasi dan data yang menunjang, sedangkan penelitian dilakukan dari Maret hingga Mei 2013.

\section{Metode analisis}

Analisis data dilakukan secara deskriptif kuantitatif. Menurut Herjanto (2008) peramalan dapat dilakukan secara kuantitatif maupun kualitatif. Pengukuran secara kuantitatif menggunakan metode statistik, sedangkan pengukuran secara kualitatif berdasarkan pendapat (judgement) dari yang melakukan peramalan.

Untuk peramalan ini peneliti menggunakan metode proyeksi tren (Trend Projection). Menurut Heizer dan Render (2009) metode proyeksi tren yaitu mencocokkan garis tren pada serangkaian data masa lalu, kemudian memproyeksikan garis pada masa datang untuk peramalan jangka menengah dan jangka panjang

Peneliti memutuskan untuk membuat garis tren lurus dengan metode statistik, sehingga dapat diterapkan metode kuadran terkecil. Menurut Heizer dan Render (2009) garis kuadran terkecil dijelaskan dengan titik potong sumbu y (dimana grafik bersilangan dengan sumbu y) dan kemiringannya (sudut garisnya). Sehingga didapatkan titik potong sumbu y dan kemiringannya, maka persamaannya dapat dinyatakan sebagai berikut :

dimana,

$$
\hat{y}=a+b x
$$

$\hat{y} \quad=$ nilai hitung dari variabel yang akan diprediksi (variabel terikat),

a = persilangan sumbu $\mathrm{y}$,

$\mathrm{b}=$ kemiringan garis regresi (atau tingkat perubahan $\mathrm{y}$ untuk perubahan

yang terjadi di $x$ )

$\mathrm{x} \quad=$ variabel bebas (dalam kasus ini adalah waktu).

Sedangkan Kemiringan $\mathrm{b}$ ditemukan dengan persamaan sebagai berikut: 


$$
b=\frac{\sum x y-n \bar{x} \bar{y}}{\sum x^{2}-n \bar{x}^{2}}
$$

dimana:

$\mathrm{b} \quad=$ kemiringan garis regresi,

$\Sigma \quad=$ tanda penjumlahan total,

$\mathrm{x}=$ nilai variabel bebas yang diketahui,

$\mathrm{y} \quad=$ nilai variabel terikat yang diketahui,

$\bar{x} \quad=$ rata-rata nilai $\mathrm{x}$,

$\bar{y} \quad=$ rata-rata nilai $\mathrm{y}$,

$\mathrm{n} \quad=$ jumlah data atau pengamatan.

Untuk menghitung titik potong sumbu y, a, dapat menggunakan persamaan sebagai berikut:

$$
a=\bar{y}-b \bar{x}
$$

\section{HASIL DAN PEMBAHASAN}

Perekonomian Kabupaten Garut dari tahun ke tahun selalu didominasi oleh produksi dari sektor pertanian, khususnya tanaman pangan. Dengan komposisi ini Garut dapat dikatakan sebagai kabupaten yang berbasis pertanian. Oleh karena itu, kebijakan pengembangan ekonomi Kabupaten Garut harus memberikan perhatian khusus kepada pengembangan ekonomi rakyat terutama di daerah perdesaan, untuk meningkatkan kesejahteraan petani. Sektor pertanian ini dijadikan andalan Kabupatan Garut agar mendapat peluang mendorong roda ekonomi Garut khususnya, juga bisa turut andil dalam perkonomian Jawa Barat.

Salah satu misi pemerintah Kabupaten Garut dalam mensukseskan visinya tahun 2009-2014 ialah dengan mengembangkan ekonomi kerakyatan berbasis agrobisnis, agroindustri dan pariwisata disertai pengembangan budaya lokal. Untuk pencapaian tersebut Kabupaten Garut juga perlu memperhatikan pasokan pangan dan energi dalam daerah dan juga menjaga pertumbuhan ekonomi mencapai 4,5 persen sesuai yang terdapat dalam Rencana Kerja Pemerintah Daeran (RKPD) Kabupaten Garut tahun 2010. Pencapaian sasaran tersebut dilakukan dengan menjaga pertumbuhan ekonomi di tahun 2010 agar tidak turun, sehingga fokus yang lebih besar ditujukan pada sektor-sektor unggulan yang diantaranya sektor pertanian (Pemerintah Kabupaten Garut, 2010).

Upaya Pemerintah Kabupaten Garut dalam memenuhi kebutuhan kedelai tidak hanya menjalankan program pertanian dari pemangku kebijakan tingkat daerah saja, namun program yang besar merupakan program yang bersifat nasional yang dikeluarkan langsung oleh Presiden dan juga Kementrian Pertanian Republik Indonesia. Kebijakan ini berkaitan langsung dengan peningkatan produksi, luas panen, penyediaan benih sampai pada pengamanan 
harga jual yang akan diterima petani dan juga penyaluran hasil produksinya.Kedelai menjadi bahan pangan ketiga yang sangat dibutuhkan oleh penduduk Indonesia dalam pemenuhan kebutuhan jasmani, tidak jauh berbeda dengan Kabupaten Garut yang ditempati oleh kurang lebih 2.606.400 jiwa dari data terakhir tahun 2018 yang didapat peneliti dari BPS Kabupaten Garut. Dengan jumlah penduduk sebanyak itu, tentu tidak mudah untuk menyediakan segala yang dibutuhkan warganya termasuk kedelai yang rata-rata dikonsumsi sebanyak 27,9 gram/kapita/hari atau 10,18 Kg/kapita/tahun. Sehingga untuk kebutuhan di tahun 2011 saja Kabupaten Garut harus menyediakan kedelai sebanyak 26.533,2 ton dan seperti yang telah peneliti sebutkan sebelumnya, produksi kedelainya masih belum mencukupi untuk dapat memenuhi jumlah kebutuhan tersebut. Pertumbuhan penduduk di Kabupaten Garut selalu meningkat setiap tahunnya, peningkatannya rata-rata mencapai 34.161 jiwa per tahun yang berarti kebutuhan kedelai yang harus tersedia meningkat 347,88 ton per tahun.

Kedelai menjadi bahan pangan ketiga yang sangat dibutuhkan oleh penduduk Indonesia dalam pemenuhan kebutuhan jasmani, tidak jauh berbeda dengan Kabupaten Garut yang ditempati oleh 2.445.911 jiwa dari data terakhir tahun 2011 yang didapat peneliti dari BPS Kabupaten Garut. Dengan jumlah penduduk sebanyak itu, tentu tidak mudah untuk menyediakan segala yang dibutuhkan warganya termasuk kedelai yang rata-rata dikonsumsi sebanyak 27,9 gram/kapita/hari atau 10,18 Kg/kapita/tahun. Sehingga untuk kebutuhan di tahun 2011 saja Kabupaten Garut harus menyediakan kedelai sebanyak $24.907,93$ ton dan seperti yang telah peneliti sebutkan sebelumnya, produksi kedelainya masih belum mencukupi untuk dapat memenuhi jumlah kebutuhan tersebut. Sedangkan pertumbuhan penduduk di Kabupaten Garut selalu meningkat setiap tahunnya, peningkatannya pun rata-rata mencapai 34.161 jiwa pertahun yang berarti kebutuhan kedelai yang harus tersedia meningkat 347,88 ton pertahun.

Kebutuhan kedelai semakin meningkat tiap tahunnya seiring dengan terus bertambahnya jumlah penduduk di Kabupaten Garut. Dalam menentukan kebutuhan yang ingin kita ketahui, terlebih dahulu harus kita dapatkan proyeksi jumlah penduduk untuk tahun yang akan diproyeksikan. Untuk mengetahui proyeksi jumlah penduduk ini peneliti menggunakan data time series dari data kependudukan, untuk menghitung peramalannya peneliti menggunakan proyeksi tren dan membuat garis trennya dengan metode kuadran terkecil. Dari hasil perhitungan permalan jumlah penduduk maka didapatkan persamaan untuk analisis peramalan sebagai berikut:

$$
\hat{y}=a+b x=2.155 .265,056+31.809,3 x
$$


Dengan persamaan diatas kita dapat memperoleh proyeksi jumlah penduduk yang ada di Kabupaten Garut di tahun 2012 dan tahun-tahun berikutnya. Untuk memproyeksikan jumlah penduduk di tahun 2012 (x10) maka kita tentukan tahun tersebut sebagai tahun ke 10 atau $x=10$, karena $x 1$ adalah tahun 2003 sehingga persamaannya menjadi;

$$
\begin{aligned}
\hat{y}=a+b x & =2.155 .265,056+(31.809,3 \times 10) \\
& =2.155 .265,056+318.093 \\
& =2.473 .358,056
\end{aligned}
$$

Jadi, pada tahun 2012 diperkirakan bahwa Kabupaten Garut akan didiami oleh 2.473.358 jiwa, atau bertambah 27.447 jiwa (1,109 persen) dari tahun 2011. Dengan proyeksi kebutuhan kedelai untuk tahun 2012 sebesar 25.178,44 ton, jumlah produksi sebesar ini menjadikan Kabupaten Garut masih mengalami kekurangan produksi kedelai untuk konsumsi warganya, karena dalam data terakhir Dinas Tanaman Pangan dan Hortikultur Kabupaten Garut untuk tahun 2012 menunjukkan bahwa produksi kedelai mencapai angka 21.462 ton atau 14,79 persen lebih kecil dari kebutuhan yang harus dipenuhi Kabupaten Garut.

Sedangkan untuk meramalkan kebutuhan 5 tahun berikutnya atau jumlah proyeksi penduduk pada tahun 2017 ( $x=15)$ kita kembali menggunakan persamaan di atas, sehingga perhitungannya menjadi;

$$
\begin{aligned}
\hat{y}_{1}=a+b x & =2.155 .265,056+(31.809,3 \times 15) \\
& =2.155 .265,056+477.139,5 \\
& =2.632 .404,556
\end{aligned}
$$

Hasil perhitungan di atas menunjukkan proyeksi jumlah penduduk di tahun 2017 yang berjumlah 2.632.405 jiwa. Dengan angka tersebut kemudian dapat kita prediksi kebutuhan kedelai untuk Kabupaten Garut tahun 2017 yaitu mengkalikan jumlah tersebut dan kebutuhan kedelainya yang hasilnya menunjukkan angka 26.807,96 ton.

\section{Peramalan Penyediaan Kedelai}

Peramalan produksi kedelai sebagai upaya proyeksi kemampuan penyediaannya untuk penduduk di Kabupaten Garut 5 tahun kedepan atau tahun 2017, dapat dilakukan dengan analisis time series berdasarkan metode peramalan kuadran terkecil.. Hasil perhitungan peramalan yang telah diperoleh, persamaan yang peneliti dapatkan adalah sebagai berikut:

$$
\hat{y}=a+b x=4.945,733333+1.247,284848 x
$$


Dengan persamaan tersebut, dapat kita proyeksikan berapa jumlah produksi yang akan Kabupaten Garut hasilkan pada $x=15$ (tahun 2017). Sehingga perhitungannya menjadi;

$$
\begin{aligned}
\hat{y}_{2}=a+b x & =4.945,733333+(1.247,284848 \times 15) \\
& =4.945,733333+18.709,27273 \\
& =23.655
\end{aligned}
$$

Hasil perhitungan peramalan produksi kedelai yang telah diperoleh menunjukkan bahwa pada tahun 2017 produksi kedelai di Kabupaten Garut mencapai 23.655 ton. Jumlah tersebut kita bandingkan dengan proyeksi kebutuhan yang telah kita dapatkan sebelumnya yang mencapai 26.807,96 ton, dengan jumlah tersebut dapat kita simpulkan bahwa Kabupaten Garut di tahun 2017 masih belum dapat memenuhi kebutuhan kedelai sama seperti sebelumnya pada proyeksi tahun 2012 yang mengalami minus sebesar 14,79 persen.

\section{KESIMPULAN DAN REKOMENDASI KEBIJAKAN}

Berdasarkan hasil analisis dalam pembahasan sebelumnya, dapat disimpulkan bahwa kemampuan Kabupaten Garut dalam penyediaan kedelai yang siap dikonsumsi pada tahun 2012 belum dapat memenuhi kebutuhan penduduknya, dengan produksi kedelai sebesar 21.462 ton dan kebutuhan kedelai diprediksi akan berjumlah 25.178,44 ton. Sedangkan tahun 2011 jumlah produksi kedelainya masih mengalami kekurangan yang cukup besar yaitu 38,15 persen dalam pemenuhan konsumsi penduduknya.

Pada 5 tahun ke depan atau tahun 2017, Kabupaten Garut diramalkan akan menghasilkan kedelai sebesar 23.655 ton dan kebutuhannya sebesar 26.807,96 ton, artinya produksi kedelai yang dihasilkan di Kabupaten Garut diprediksi masih akan mengalami defisit untuk memenuhi kebutuhan konsumsi kedelai penduduknya dan juga merealisasikan program dari pemerintah. Untuk dapat memenuhi kebutuhan kedelai, perlu diupayakan intensifikasi (peningkatan produksi persatuan luas) dan ekstensifikasi (peningkatan produksi dengan perluasan tanam). Adanya impor kedelai atau pemasukan kedelai dapat dilakukan untuk memenuhi kebutuhan konsumsi penduduk yang melebihi dari kemampuan produksi. Swasembada yang diperkirakan masih belum dapat terealisasi, merupakan acuan untuk mendorong program-program Dinas Pertanian Kabupaten Garut dan instansi lain yang mengurusi bersama program tersebut agar selalu memberikan penyuluhan, motivasi bersama dan jaminan kepada petani penggarap. 


\section{DAFTAR PUSTAKA}

Badan Penelitian dan Pengembangan Pertanian. 2005. Rencana Aksi Pemantapan Ketahanan Pangan 2005-2010. Departemen Pertanian. Jakarta.

Badan Pusat Statistik. 2009. Statistik Nilai Tukar Petani Di Indonesia. Jakarta.

Badan Pusat Statistik Kabupaten Garut. 2012. Kabupaten Garut Dalam Angka 2012. Garut.

Badan Pusat Statistik Provinsi Jawa Barat. 2012. Jawa Barat Dalam Angka 2012. Bandung.

Bowo. 2011. Gubernur Jawa Barat Genjot Pangan Berbahan Baku Lokal. Ahmadheryawan.com [diunduh pada 18/04/2013]

Dinas Tanaman Pangan dan Hortikultura Kabupaten Garut. 2012. Rekapitulasi Tanaman Pangan dan Hortikultura 2003-2012. Garut.

Heizer, J dan Render, B. 2009. Manajemen Operasi (Penerjemah: Chriswan Sungkono). Salemba Empat. Jakarta.

Herjanto, E. 2008. Manajemen Operasi (Edisi Ketiga). PT. Grasindo. Jakarta.

Pemerintah Kabupaten Garut. 2010. Rencana Kerja Pemerintah Daerah (RKPD) Kabupaten Garut 2010. Garut.

. 2013. Animo Petani Garut Tanam Kedelai Turun Drastis. www.garutkab.go.id [diakses pada 18/04/2013]

Utomo, Y. 2012. Soal Pangan, Indonesia Menyedihkan. Kompas.com [diakses pada 18/04/2013] 